\title{
MONOPOLISTIC COMPETITION IN DISTRIBUTION
}

\author{
ReINHOLd P. WOLFF*
}

\section{MONOPOLY REDEFINED}

Modern economics defines our present price structure as a synthetic product in which economic elements of both competition and monopoly have been blended. ${ }^{1}$ Although the nature and effects of monopolistic competition in production have attracted wide interest among economists, lawyers, and governmental agencies, the field has been little explored as far as the distributive trades are concerned.

While in production and transportation the octopus of monopoly was being scientifically dissected and its parts analyzed, the analysts lost cognizance of the original goal of their analysis. They came to associate the evidence of the phenomenon with the phenomenon itself, price fixing with monopoly. They forgot that the whole theory of competition is essentially based on the assumption of a balance between production and consumption which should be obtained through the medium of a free price, and that this very balance, not free price, constitutes its essence. Particularly have the courts, which are required to cast economic theory into the mould of a legal formalism, failed to segregate the paraphernalia of monopoly from this essential maintenance of balance. They have failed to recognize big business as the largest threat to the balance of competitive forces.

The courts and many students of economics also frequently overlook some distinct features which give to operation of monopoly in the distributive trades a different aspect from what has been observed in manufacturing industries. Unlike his manufacturing counterpart, the large-scale dealer is more often both a monopolistic seller and buyer. The distributor, as the middleman between a large number of producers and a still larger number of consumers, holds a key position in the mechanism which determines the price to the ultimate consumer. To the proper balance of the system it is as important that competitive buying prevails as it is that there are rival sellers. If there is a monopolistic buyer or "monopsonist," as science calls him, the balance is disturbed. ${ }^{2}$ A surplus profit occurs for the buyer, which has been called "consumer's surplus," that is comparable to the monopoly

\footnotetext{
- Ph.D., 1920, University of Freiburg. Former member of the Bar of Berlin. Assistant Professor of Economics at the University of Miami. Author of various writings on cartels, pricing, and marketing. This research has been assisted by a grant-in-aid of the Social Science Research Council.

2 Chamberlin, The Theory of Monopolistic Competition (i933); Robinson, The Economics of IMPERFECT COMPETITION (1932, repr. ed. 1938).

'The theory of monopolistic buying is ably discussed by Rosinson, loc. cit. supre note $\mathrm{I}$, to whom we also owe a development of the idea of the "consumer's surplus."
} 
profit harvested by the monopolistic seller. This profit exacted by the monopolistic buyer tends to prevent the allocation of productive resources to the consumptive use of largest marginal utility, a goal which is as important to society as low consumer price. This connection has frequently been misunderstood by economic analysts who are inclined to identify the public interest with the interest of the consumer in low price. As a consequence the public attitude toward monopolistic competition has generated inconsistent and non-uniform policies productive of serious impediments to efficient marketing.

The flow of goods from the producer to the consumer is comparable to a stream in which currents of unequal strength mingle. If barriers are erected to the free flow of the river, impediments are created which may retard the flow of some currents while accelerating others. Monopolistic competition in distributive trades may be compared to a river in which such wilful impediments have been erected. The obstacles tend to retard the free flow of some goods but they may also have the opposite effect of spurring others, of regulating and equalizing the stream of commerce. Imperfect competition, therefore, cannot be looked upon as an entirely anti-social force; some of the trade barriers to be found in distribution will have to be recognized as beneficial to marketing.

\section{Concentratron in the Distributive Trades}

Only during the last thirty years has concentration of enterprise appeared in distributive trades. In its extent it continues to lag behind similar developments in the production and transportation industries. ${ }^{3}$ Various reasons account for the preservation of small businesses in wholesaling and retailing. By their very nature, distributive trades, especially retailing, are conducted on a small scale. The individual transaction deals with small units of merchandise. At the retailing end, it involves close personal contact with the customer and implies the features of conservative trading methods that go with small business. In addition, there is evident lack of some factors that have created large-scale operators in other industries. There are not the requirements of large capital; there are few possibilities of achieving market control by patents. Interlocking directorates are less numerous, and control of supply conditions harder to achieve.

Nevertheless the tides of capitalistic concentration are beginning to engulf certain parts of the distributive industries. In the trend toward larger retail and wholesale units, the impetus comes from both the producing and the distributive side. Packaging and branding of manufactured articles have contributed greatly to attempts on the part of manufacturers to control retail outlets and to integrate retail operations. Skilled merchandisers among the dealers have developed methods of largescale buying and selling. Urban growth has concentrated demand on shipping

\footnotetext{
3 Twentieth Century Fund, Big Business, Its Growth and Its Place (1937) 47, 48 gives a rather vague idea of wholesale and retail concentration. Berle aNd MEANs, The MOdern Corporation and Private Property (I933) c. 3 touches on the subject. Burns, The Decline of Competition (1936) does not emphasize the concentration that has occurred in distributive trades.
} 
centers of the large cities. The motorization of transportation, the improvement of highways, the progress in refrigeration and in communications have connected formerly separated markets and facilitated their control by centralized selling and buying.

In many respects the large-scale distributor is superior to the small-scale operator. Merchandising efficiency is rare and places a premium on the effectively managed outlet. Larger capital resources allow impersonal sales promotion and advertising. Larger operators are better disciplined to deal with organized selling groups, and their superior economic power allows buying at lower cost. Experience also points to the fact that organized labor cooperates more freely with organized business than with the small establishment, and price fixing often goes hand in hand with unionized wages.

Thirty years ago the American retail business was divided into small parcels of more than a million store owners, none of them controlling any sizable portion of the market. At present, roughly one-fifth of the forty billion retail volume is dominated by some twenty-five large corporations. ${ }^{4}$ Sixteen of these corporations are engaged in retailing and exercise direct control over approximately ten percent of the retail volume. Another ten percent of the retail business is less directly controlled by the three leading automobile manufacturers and by the five large integrated oil companies. The form under which this latter control appears is partly that of direct ownership, partly agency contracts, local franchises, and store leases with so-called independent retailers. Around this cluster of highly concentrated economic control is spread a fringe of medium- and small-size retailers who still number more than a million.

The department store represents the earliest development of large-scale business in American retailing. This type now represents only about one-fourth of one percent of all retail institutions, but accounts for about nine percent of all retail store sales. Quite a considerable number of department stores have sales of one hundred million dollars in a single year and not a few have sales between ten and one hundred million dollars. Many department stores are operated by chains or combined in ownership groups. One such group, The Allied Stores Corporation, operates twenty-nine large stores in sixteen states. Most outstanding as a group with relatively small but numerous units is the J. C. Penny Company which operates more than fifteen hundred stores and accounts for almost three hundred million dollars of annual sales.

After the department store, the mail-order house made history in American retailing. The two largest organizations of this type, Sears Roebuck \& Co., and Montgomery Ward \& Co., had grown into big business enterprises long before the first World War. When the development of motor transportation deprived the mailorder house of many of the advantages of its particular type of operation, each of

\footnotetext{
- See (r938) 2 Trade Reg. Rev. No. 4. Also Beckman and Nolen, The Chain Store Problem (1938); Retail Distribution, in Census of Distriburion (U. S. Bureau of the Census, 1935); Federal Trade Commission, Chain Store Reports.
} 
these units transformed itself into a combined mail-order and chain department store organization. The tremendous importance of these two store systems, both on the buying and on the selling side of the market, is best illustrated by the fact that their combined sales volume of about a billion dollars accounts for more than two percent of all retail sales of the country.

The chain store has outgrown both the department store and the mail-order house in importance as a distributive agent. The census figures of 1935 revealed 22.8 percent of chain stores in total retail distribution. Not all chains, however, constitute big business, and the great number of medium-sized and small chains account for a considerable proportion of this total.

Corporate chain stores are most important in the price variety field where they command about nine-tenths of all sales. In this field the four largest corporate chains control about 73 percent of the total retail volume. They have a considerable share of the shoe store and the automotive accessory field and of grocery and drug distribution, but play a minor role in such fields as hardware, dry goods, and restaurant business. In the food retail trade, the corporate chains have grown by leaps and bounds. Five large chains control roughly two billions of sales or 20 percent of all food retail business, which is twice the volume of the 300,000 independent stores having individually less than $\$ 10,000$ annual sales. In the department store and apparel field three large corporations do 15 percent of the total distribution of this class. The two large mail-order chains account for roughly a billion dollars of sales. A large shoe chain controls xo percent of all men's shoes and four large chain systems do about 15 percent of the total shoe volume, the remainder of which is divided among 19,000 stores. ${ }^{\sigma}$

Of more recent date is the development of the supermarket, which has grown into an important factor in the distribution of food and which is also gradually finding entrance in the drug and variety field. ${ }^{6}$ Ten years ago there were not many more than two hundred supermarkets in the entire United States. At present their number is in the neighborhood of 5,000. Their volume of business, on the average $\$ 300,000$ annually, outranks by far the orthodox grocery store but would not justify classification as large-scale business, were it not for the fact that many systems are multiple unit organizations. Although only one organization with fifty-nine markets and $\$ 25,000,000$ annual sales has offered its stock in the investment market, the large corporate food chains have entered the supermarket field and have amalgamated some of their neighborhood units into larger markets. However, the majority of supermarkets are still operated by the independents.

\section{Vertical Integration: Manufacturers' Controls}

Hand in hand with the growth of large-scale business in the horizontal direction there has also occurred what may be called the vertical integration of distributive

'See Wolff, The Chains Adjust Themselves to State Taxation (Oct. 1939) 47 Dun's REv. 20, 22.

'See Wolf, The Rise of the Super Market and Some Marketing Consequences (Sept. 1940) 48 DON's Rev. 8 et seq. 
trades. Large-scale manufacturers have sought control over distributive outlets; largescale distributors, backward integration with producing establishments. Elements of monopolistic competition have been both the cause and the consequence of such concentration.

The reasons for which manufacturers have attempted to control distributive trades, to restrict entrance into such trades, and to regulate competition among retailers and wholesalers, are numerous. Foremost has been the desire to divert the price pressure to which producers are exposed if cut-throat competition prevails among dealers. ${ }^{7}$

Where a manufacturer advertises his product directly to the consumer, as in the drug and food lines, or in gasoline and rubber tires, control over distributive trades is frequently attempted in order to insulate a manufacturer's profit from the shock that it may receive from more efficiently distributed rival products. Especially do manufacturers who distribute via jobbers and independent retailers thus insure their sales volume against competition from products which are distributed direct to chain stores or supermarkets.

Where producers operate under high fixed costs, the maintenance of a steady demand may be expedient, and the control of distributive channels mandatory. The manufacturer's endeavors will here be directed rather toward the maintenance of recurrent dealer demand than toward an extraordinarily large volume of business, a purpose that is best accomplished by a limitation of the number of distributors.

Recently imperfections of the market have resulted from manufacturers' attempts to check the progress of dealer brands. Such private brands for wholesalers, mailorder houses, department stores, cooperative groups, and supermarkets have become a large threat to the national brand. They are frequently packed by manufacturers dependent or even indirectly owned by dealers. Vertical integration by manufacturers stands here against vertical control by dealers, a fact which demonstrates again the synchronization of competition and monopoly.

The means of manufacturers' control over distributive markets vary as between trades and manufacturers of varying size and strength. They range all the way from loose contractual relations to complete integration of distributive outlets. They embrace both the wholesale and the retail trade. We find them in local selling and in national distribution as well. The most intimate control a producer is able to exercise over the channels of distribution is the virtual absorption of all retail outlets. ${ }^{8}$ Such direct distribution to consumers is, however, very infrequent. Only 2.4 percent of all manufactured articles are directly routed to the consumer buyer. ${ }^{9}$ The practice is important in bread markets and for certain household articles. A far-reaching attempt to integrate retail outlets has also been undertaken by oil refiners but is now being abandoned by most operators.

\footnotetext{
${ }^{T}$ See Gretrer, Price Control Under Fatr Trade Legislation (1939) c. Io.

${ }^{8}$ The nature and effect of vertical integration are described in BurNs, op. cit. supra note 3 , at $4 \times 8$ et seq.

-Distribution of Manufacturer's Sales, in CENsus of Business: I935 (U. S. Dept. Com., I937).
} 
More successful have manufacturers been in integrating wholesale activities. Especially since the appearance of chain stores, producers have undertaken nationwide distribution through their own wholesale establishments of such products as food, drugs, hardware, liquor, radios, automobiles, automobile tires, and office equipment. The manufacturer maintains either a sales office or a warehouse in the important trading centers from coast to coast and makes deliveries at least either f.o.b. factory or through a trucking system from the distributing centers. The advantage to the manufacturer is the elimination of all competition at the wholesale end and a possible control over retail markets. Not infrequently a direct savings in warehousing, transportation, and management has thus been effected. ${ }^{10}$

Quite evidently direct distribution is open only to the large manufacturing concern with wide national markets and broad financial resources. Smaller manufacturers have generally preferred to distribute through jobbers or brokers. But they have attempted in a similar way to eliminate friction in the wholesale stage of distribution. One method of achieving this end has been the granting of franchises to wholesalers; to individual jobbers are allotted sales territories within which competition is wholly eliminated. Another method, growing recently in importance, has been the withholding of the product from outlets which compete with the jobberretailer channel; for instance, no sales are made to chain stores, mail-order houses or other direct buyers. In both events a situation is created in which competition is intentionally lessened.

Direct retail-price control has become customary for the higher-priced cosmetics, for refrigerators, automobiles, radios, and office equipment. Territorial restrictions or branch restrictions are imposed on retail distributors. Some manufacturers distribute through only a few retail outlets in each city; others restrict sales to dealers who are likely to promote the item, withholding it-notably from price-cut stores. Since the Robinson-Patman enactment, manufacturers have frequently concentrated on either independent or chain stores. Others have withheld their products from syndicate chains or mail-order houses. In order to avoid friction between their retail outlets some producers have followed up selective distribution with selective packaging. The product is sold under the various trademarks or in different packages to independent stores, on the one hand, and to chain stores, on the other, or separately to drug and five and ten stores. ${ }^{11}$ Since the Miller-Tydings Act legalized resale price maintenance in interstate commerce, the method of maintained retail prices has become customary in drug lines, in the book, liquor, and tobacco industries, and in selective groups of foods and dry-goods articles.

Apart from direct attempts to control retail outlets or retail prices, or both, manufacturers have used various methods of securing recurrent sales, such as long-term contracts with dealers, volume rebates, and other cumulative discounts. Significant economic effects have resulted from these various controls of manufacturers. Most

\footnotetext{
${ }^{10}$ See Beckman and Engle, Wholesaling Principles and Practice (1938) c. 13.

${ }^{11}$ See Harung, Retail Price Cutting and Its Control by Manufacturers (1935) 135 el sed
} 
noteworthy are serious imperfections in wholesale and retail markets. Increasingly larger portions of retail outlets have been brought into partial dependence upon, if not under direct control of, manufacturers. In some branches retailers have become virtual agents of the producer and have been entirely deprived of their freedom of selecting goods in the interest of the consumer. Instead of being an instrument for expressing market demand, such retail outlets have been chained to the supply side of the market, leaving the consumer without a proper representative in the array of marketing forces.

\section{Market Control by Dealers}

In contrast to the foregoing practices which deal with producer-imposed market controls, we find also numerous controls imposed by dealers. Some of these controls operate in horizontal direction, while others present examples of vertical integration.

Relatively seldom do retailers or wholesalers resort to horizontal price fixing. ${ }^{12}$ The larger number of sellers in distributive trade, the overlapping of their sales territories, and the lack of organizational discipline do not encourage price agreements among dealers. Occasionally such price control organizations are found in the drug field, in some lines of food trades, in the liquor industry, in some dry-goods trades, and particularly in the dairy field. Their strength varies as between trades and localities. Most commonly they are operating in limited local territories. They have reached considerable strength only in markets where state interference became an organizing factor, such as in the dairy industry, and in the pharmaceutical and liquor trades.

In modern retailing the most controversial practice is the loss leader. ${ }^{13}$ The selling of articles at a loss or at no profit is a weapon that large-scale distributors, such as department stores, mail-order houses, chain stores and supermarkets have used against their smaller competitors. The loss leaders attract patronage from large trade areas. Especially advertised articles with a strong popular appeal became a favorite subject of price cutting. For the most part it was department stores, mailorder houses and chain organizations in the drug, liquor and tobacco field which used bargain sales; but gradually all types of retail stores were pulled into the whirlpool of price slashing. The margins of nationally advertised articles were depressed to a point which left no profits to their distributors, and thus indirectly injured the interests of their producers.

More recently loss-leader selling has assumed new aspects. Certain kinds of distributors, such as large department stores and some of the food chains, have denounced extreme forms of the practice. On the other hand, the method has gained importance as a less spectacular method of underselling. Department stores and supermarkets sell a large number of aggressively advertised standard brands at

${ }^{12}$ As to the various price and market controls introduced in production industries, see particularly Burns, loc. cit. sipra note 3; Watkins, Public Relations of Competitive Practices in Business ENTERPRISE (I940).

${ }^{13}$ Sec Seligman and Love, Price Cutting and Price Matntenance (i93i); Grether, op. cit. supra note 7 , at I99-224. 
lower than average mark-ups but at no loss, in order to gain a reputation for reasonableness, while less advertised products, private brands, and unadvertised products of smaller manufacturers are carried at much higher mark-ups.

Again we are confronted here with imperfection of the market in that smaller rivals are unable to compete on the same level. The smaller retailer has to concentrate on items for which advertising has created wide consumer acceptance and recurrent consumer demand. He is unable to carry a large stock of slow moving items with higher mark-ups. Thus he finds himself unable to balance the loss from the price-cut items by higher prices on less advertised products. The lack of price information on the part of buyers operates to accentuate this imperfection. If consumers were fully informed about the price and quality of offerings they would realize that the impressive bargain front of the larger store hides many non-competitive articles with high mark-up, especially private brands of wholesalers and retailers.

Through the development of large-scale distribution, other monopolistic practices that we know from manufacturing industries have found entrance into the distributive trades. One such practice is the shifting of competition from price to service, selection, convenience, delivery and credit. ${ }^{14}$ There evidently exists a cycle which runs through all stages of retailing. Large-scale distributors build up volume by rugged price competition, curtailing service, credit and delivery to a minimum. After having amassed considerable volume in their stores they introduce service features which increase their fixed cost and demand the maintenance of high profit margins and stable prices through intensified promotional pressure and enhanced services. This is what has happened in the department stores and mail-order houses, where margins have doubled during the last decade. In the chain-store and supermarket field similar trends are observable.

To a certain extent the goal figures of departmental accomplishments are working in the same direction of enhancing prices. These goal figures are guides to the department store manager in his control of buying prices, overhead expenses, and mark-downs. To the extent that the large stores are price leaders in their respective fields, the goal figures will tend to raise margins of other stores and thereby heighten prices to the consumer.

This price leadership of large operators is a phenomenon which has been particularly studied in production industries such as steel, meat packing and tobacco, ${ }^{15}$ but is as frequent in distributive trades. Price leaders are to be found in almost every field in which large distributors account for a considerable portion of the total retail volume. The two large mail-order houses, the big corporate department stores, the national food chains, the chain drug stores are all occasionally assuming the

\footnotetext{
${ }^{14}$ Some authors, such as Burss, op. cit. supra note 3 , at 372 et seq., include advertising in these imperfections. It may be asked, however, whether intensified advertising in retailing, in linking separate markets, has not increased rather than decreased price competition.

${ }^{16}$ See instances and economic analysis in BurNs, op. cit. supra note 3 , at 77-145. For price leadership occurring in the gasoline retail industry, see Till, Gasoline: The Competition of Big Business, in Hamalton, Price and Price Policies (1938) 117, at 126.
} 
rôle of price leaders in their respective fields. The two large dairy distributors and the integrated gasoline distributors have become established as price leaders in many markets. Price leadership is of varying impact on the market depending upon local conditions. Quite naturally, in a small community with a few stores a national chain organization would have a larger importance as a price leader than would a large department store in a city where there exist many competitors in specialized lines. A mail-order chain unit may be a price leader in the automobile accessory field while in men's furnishing lines it may be of little importance for the price structure of the community.

\section{Monopolistic Practices of Large-Scale Buyers}

The major imperfections of our distributive markets appear on the buying as well as on the selling side of the market and find their causes directly in the concentration of the distributive trades.

The "monopsonistic" buyer, as defined by economic theory, harvests a "consumer's surplus" at the expense of the competitive seller. ${ }^{16}$ One practical materialization of the buying monopoly is the volume discount exacted by both syndicated buyers and individual purchasers. The volume or cumulative discount is given in consideration of the larger volume which an individual concern or group of buyers places with an individual seller. Not being related to the quantity of the individual order, it therefore has no direct connection with the cost to the seller. It presents perhaps the clearest form of a price discrimination in favor of larger retailers. It creates an imperfection of the market in that it places a small distributor at a distinct disadvantage and has been condemned as harmful competition since it does not reflect larger marketing efficiency. ${ }^{17}$ Yet the volume discount like other forms of cumulative rebates has appeared ${ }^{18}$ and will appear wherever close business connections are established between the large buyer and individual sellers. ${ }^{19}$

The quantity discount, more closely related to the cost concept, may represent direct savings of cost. Yet, since it is not always thus related, it has become the subject of extended controversy. ${ }^{20}$ Carload buyers, especially in the department store, chain and supermarket fields are able to buy at considerable cost differentials. The argument in favor of the quantity discount is that smaller distributors could obtain the same advantage if they would pool their purchases in cooperative buying. Practically, however, only a limited group of retail outlets lend themselves to cooperative action of this kind. Because of the tremendous diversification of lines handled in a

${ }^{10}$ See Robinson, op. cit. supra note $\mathrm{I}$, at 223 .

${ }^{17}$ Cf. H. C. Brill Co., Inc., 26 F. T. C. 666 (1938).

${ }^{28}$ A typical situation of this type exists in the clothing trades, especially in the ready-to-wear dress trade where large buyer syndicates are dealing with small-scale sellers. Meiklejohn, Dresses: The Impact on a Business, in HAMLTON, op. cit. supra note 15 , at 370 .

${ }^{10}$ See as to this question and other discrimination problems Oppenhem, Recent Price Control LAws (1939) 123, and bibliography, 125. See also George, The Robinson-Patman Act Begins to Acquire Meaning (March 1940) 48 DuN's REv. 20 et seq.

${ }^{30}$ See particularly the controversy centering around the Kraft-Phenix Corp. policy of a combined volume and quantity discount; also address of Federal Trade Commissioner Freer, March 24, 1938. 
modern store, central buying requires centralization of management which independent outlets rarely are able to accomplish. The quantity discount, therefore, has to be considered as a distinct advantage to the large seller and cannot fail to encourage further concentration in businesses where it prevails.

Certain forms of indirect price discrimination, through disguised rebates, advertising allowances, favoritism in services, push money items and demonstrators have been the object of frequent discussions in trade circles. Their partial suppression by the Robinson-Patman Act has not entirely removed them from the retail scene and there can be no doubt that they continue to constitute imperfections of the market.

More serious trade impediments stem from attempts of buying groups to fix uniform purchasing prices. Outstanding among such bargaining attempts is the fixing of the base price for milk to be paid to farmers and agreed upon by the large milk dealers on the one hand and farm cooperatives on the other. Buyers are motivated by a desire to prevent competitive bidding among themselves for the available supply, and to secure a regular flow of supply throughout the year for such seasonal products as dairy products, eggs, fresh fruit and vegetables. It has been charged that large buyers in these markets exert monopolistic power over the widely scattered farmers. Sellers lack organization and in addition are subject to the pressure that the perishable nature of these products exerts on the market. Thus legitimate attempts on the side of buyers to regulate the flow of products to the advantage of both sellers and buyers are inseparably interwoven with efforts to tip the scales of marketing in favor of the better organized dealer groups. ${ }^{21}$

\section{Public Policies Toward Monopolistic Practices as Marketing Barriers}

Public policies toward monopolistic practices in distributive trades are not uniform. Inspired by contradictory motives, they have created unequal results and quite often form barriers to effective marketing.

As the legal background of these policies we still find the anti-trust laws, which were written into the state and federal statute books long before our present system of distribution had emerged. These laws were devised to cope with phenomena arising in production and transportation industries, but did not lend themselves to the adjustment of conflicts arising under the quite different circumstances which prevail in distributive trades. The courts also failed to take cognizance of the reversal of economic forces in distribution. They frequently condemned concerted action among smaller merchants while the exploitation of atomized sellers by collective action of syndicated buyers, chains, and other powerful groups escaped legal attack. ${ }^{22}$ As a consequence the anti-trust acts have been favorable rather than detrimental to the

${ }^{2 x}$ This is particularly true in many milk markets, where two large distributor groups exercise controlling influence. See the analysis by Till, in Hamrzton, op. cit. supra note 15 , at 474-482. Sec also various reports of the Federal Trade Commission on the Sale and Distribution of Milk and various releases of the Department of Justice in cases against the Borden Corp. and National Dairy Products Corp., ro6 C. C. H. 2 Trade Reg. Serv. (8th ed. 1937-1940) 17,004, 17,009, 17,012, 17,041.

${ }^{22}$ Meiklejobn, supra note 18 , points out, at 363 : "The dress manufacturers are in a far weaker bargaining position than the organized buyers. If they attempt combination, as the dress guilds did when they agreed to refuse to grant special discounts, they are guilty of restraint of trade." 
development of monopolistic competition in distributive trades. They have not imposed checks on the growth of large-scale enterprise, have indirectly favored both vertical and horizontal integration, and have prevented small-scale enterprise from seeking salvage in cooperative organization.

Only with the depression did there come a partial reversal of this public attitude. The N.R.A. brought the small businessman to Washington and many of the codes of unfair competition took cognizance of the plight of the independent retailer and wholesaler in his struggle with his superior competitor. The N.R.A. was shortlived, but the cooperative spirit that had been generated through compulsory organization under the N.R.A. codes showed a more than ephemeral vitality. Directly sponsored by local N.R.A. groups, fair trade committees sprang up all over the country and raised the battle cry for legislative protection of the small independent businessman.

Foremost in the center of this legislative drive have been two practices-the loss leader and price discrimination. The economic philosophy which dominated prosecution policy under the Sherman and Clayton Acts had considered both price discrimination and aggressive price leaders as a form of price competition which only in extreme cases could upset marketing equilibrium. The law-enforcing agencies were committed to a theory of price equilibrium which did not take cognizance of the phenomenon of "monopsony" on the buying side of the market. But the people in Main Street frequently had a more realistic conception of the threat of large-scale enterprise and made energetic efforts to reverse public attitude.

Gradually the influence of small independent retailers succeeded in swinging the legislators toward their side. One state after another adopted laws which endorsed the independents' viewpoint and were pointed against big business. Technically most of these laws appeared as amendments to the state anti-trust laws and lifted price-fixing prohibitions or forbade price discrimination. Almost all of them adopted names that suggested a relationship to the concept of fair competition and trade.

As in many other fields of commerce, existence of non-uniform state and federal laws created an impediment to trade. One such divergence of attitude between federal and state authorities developed in regard to resale price maintenance. The drive for permissive legislation to allow vertical contractual price fixing was started by organized groups especially in the drug trade. It came as a reaction to the widespread use of nationally advertised, branded articles as loss leaders in the trade. The campaign for such permissive legislation succeeded in most of the states and led to the enactment of Fair Trade Acts. ${ }^{23}$ These acts not only allowed manufacturers to fix uniform retail prices for their products but also forbade the underselling of such fixed prices by non-contract dealers. From the viewpoint of the national manufacturer, the legislation created a confused marketing situation. While under federal law it was unlawful to impose a contractual limitation on the retail price, under

\footnotetext{
${ }^{23}$ See analysis of these acts in GretHer, op. cit. supra note 7, Appendix A, 403. Also, ro6 C. C. H., stipra note 2r, at ro,oor et seq.; Oppenheim, Recent Price Control Laws (r939) Pt. I, at 62. States having these laws now total 44 .
} 
the law of many states the observance of fixed prices was mandatory. The federal Miller-Tydings Act of 1937, freeing interstate price maintenance from the restrictions of the Sherman Act, restored the balance between contradictory federal and state legislation. Under the new policy contractual price maintenance has been widely practiced by both local and national distributors.

Yet the fair trade movement was unable to shift the marketing balance to the side of the small independent retailer. The much publicized effects of resale price maintenance should be taken with a grain of salt. Laborious statistics have been compiled and presented by trade groups to demonstrate that resale price maintenance has enhanced the cost of living or that it has not. To the informed specialist, these statistics have hardly added much that he did not know before. The layman and the less informed economists have been misled into believing that Fair Trade Acts have created major shifts in distribution. Probably there is not a single field in which any change in distributional methods can be directly ascribed to the law. A single exception is perhaps furnished by the drug and cosmetic industries. The drug stores' minimum margins for national items previously subject to intensive loss-leader selling have been established and well enforced. But even in this field the general effect of the price stabilization on the industry has been relatively small, because retail competition was shifted to non-protected items, private brands and second grades. In the liquor field minimums were fixed by manufacturers of most national items, but the continuous price warfare, especially at holiday seasons, is testimony of the unsatisfactory enforcement of the acts. In the tobacco field four out of five large cigarette distributors have chosen to leave their prices unrestricted and in the food field price maintenance efforts are limited to a few brands which are only small islands in the big seas of distribution. In such industries as hardware, radio, and gasoline, price stabilization efforts under the Fair Trade laws have scored only ephemeral success.

Another trend of legislative thought is embodied in the Unfair Sales Acts, ${ }^{24}$ enacted in about half of the states. By forbidding sales below cost these laws provide a more elastic price rule against the loss leader. For while the Fair Trade Acts allow manufacturers of branded articles to fix a uniform retail price, the Unfair Sales and Practices Acts prohibit loss-leader use directly in defining a cost price below which retailers are not supposed to mark up their commodities. Consequently, these laws apply not only to branded but to all kinds of commodities, and they make it unlawful for the retailer to sell below a certain minimum mark-up even if the manufacturer himself does not want to have retail prices maintained. The efficient enforcement of this type of law depends entirely on the existence of a vital trade organization which supervises the price behavior of retail stores and advises the public attorney on prosecution of violators. The Floor Price laws have been frequently attacked as price fixing statutes and partly voided by federal and

${ }^{24}$ For an analysis of these acts see $i b i d$. 
state courts. It seems, however, that the principle of a minimum cost price has survived the judicial ordeal. ${ }^{25}$

The effects of Unfair Sales Acts are also less than voluminous economic discussions and government reports would suggest. Practically, only in the state of California-and here again only in the food trade-has an organized attempt been undertaken to ban the loss leader. The retailer groups were active in prosecuting chain stores, supermarkets, and also smaller price cutters. They succeeded in piling up a bulky record of court cases and administrative precedents but were unable to check the growth of chains, supermarkets, and other price-cutting retail organizations which flourish in California more than anywhere else.

In the matter of price discrimination the federal legislator has led the state law givers. Again, as in price-fixing, the legislative curative has been proposed and endorsed by pressure groups in the distributive fields. Wholesalers and independent retailers clamoured for a ban on special discounts which their larger chain-store competitors were able to exact from manufacturers and farmers. In form, the Robinson-Patman Act against price discrimination was an amendment to the Clayton Act, which already had an anti-price discrimination clause. In fact, it reflected an entirely new idea. The Clayton Act was chiefly aimed at the practice of local price differentials. Its factual background was the violent methods allegedly used by the older trusts to drive independent competitors out of business by underselling them in their local sales territories. Significant emphasis of the Clayton Act was thus on the selling side of the market.

The Robinson-Patman Act is aimed at the mass buyer. Chain stores, mail-order houses, department stores and buying syndicates have become the chief defendants in anti-trust prosecution under it. While under the Clayton Act the seller violated the law when paying extra dividends or rebates to dealers, the amendment made it illegal to accept discriminatory discounts. The economic doctrine of the consumer surplus was thus written into the law. It prohibited discriminatory discounts not justified by cost savings. Since the law operates mostly in the wholesale field including such mass retail buyers as supermarkets, chain stores, and mail-order houses, it is mostly interstate in scope, but it is supplemented for the realm of intrastate commerce by numerous state laws.

After four years of operation the Robinson-Patman Act has gained sufficient practical meaning to become an operative factor in distribution. ${ }^{26}$ To the disappointment of those who helped draft the original bill the force of the act did not carry our distributive system to the ends which the master craftsmen of the draft had anticipated. Purporting to strike a balance between the buying power of the "little fellow" and the mass distributor, the act caused some manufacturers to discontinue trade with the little fellow altogether. Others, whose lot was more clearly cast with the mass of small-scale distributors, established warehouses of their own in the distributing centers. This was definitely not to the advantage of the wholesaler

${ }^{26}$ Sec Oppenherm, op. cit. stupra note 23 , at 63 et seq.

${ }^{20}$ See George, supra note rg. 
sponsors of the act; nor have brokers had reason to rejoice at the effects of the antibrokerage clause of the act, which has caused some large national chain systems to discontinue all relations with brokers. As a whole, selective distribution has been greatly encouraged by the act. Many producers distribute now exclusively to chains or jobbers, others use specialized selling under distinct brands or with distinctive packages. Such specialized selling is undertaken to make the article less competitive in the distributive field and constitutes therefore an imperfection of the market directly traceable to the Robinson-Patman Act.

Another outstanding change in distributive practices has been seen in the discontinuance of many volume discounts. It is hard to ascertain to what extent large buyers are still able to secure such discounts in disguised form, for instance as advertising allowances, cash discounts, or in free goods. As a rule manufacturers are now more anxious to base price differentials on true cost differences; they also base advertising grants to dealers on services performed and try to arrive at price scales which classify rather than individualize.

For one thing it appears that neither the chain, the buying syndicate nor the giant superstore against which the Robinson-Patman Act was directed have been stalled in their triumphant forward march. The chains have grown larger, the buying syndicates more powerful, the mail-order houses more voluminous despite Robinson-Patman. If we try to assemble the individual marketing effects into a general picture we see no radical changes ascribable to the altered public policy.

The passing of such legislation as the Robinson-Patman Act, the Fair Trade Acts and the Unfair Practice Acts was hailed by the independents as a first victory in their drive against the chain store. More radical legislation was then proposed to prevent national chains from establishing further branches throughout the country, from intergrating wholesale activities, from manufacturing their own brands. Discriminatory-price tax bills were laid before city councils, state governments, and finally before the national legislature. The federal measure, the Patman Anti-Chain Store Bill, has gained nation-wide fame. ${ }^{27}$ The measure was twice defeated in Congress despite the considerable strength that had been assembled among members of both houses. Although under present conditions its early reappearance in Congress is not very probable, it is most significant in the rigidity of its terms. Under this law such cumulative taxes would have been laid upon all national chains as to force the largest groups in the grocery field to go out of interstate operation. Even though this federal attempt failed, it constituted a serious barrier to interstate commerce during its consideration. To the large national chain corporations its cumulative tax schedule constituted a threat to their very existence. The bill had a definite effect on chain marketing policies of the thirties. Besides, even with the

\footnotetext{
${ }^{27}$ For an analysis of the bill see The Patman Tax Bill on Chain Stores (1938) 2 Trade Rec. Rev. No. 4. See also $\mathrm{x}-4$, Hearings Before the Subcommittee of the Senate Committee on Ways and Means on H. R. $1,7^{6 \text { th }}$ Cong., 3d Sess. (1940).
} 
defeat of the Patman Bill in Congress, there is left enough state legislation seriously to stifle the growth of chain distribution. ${ }^{28}$

While some communities were able to ban supermarkets and chains altogether through city ordinances of drastic proportions though of doubtful constitutional validity, some states, particularly in the South, imposed taxes which checked the further growth of corporate chain distribution. Again it is quite significant for the haphazard effects of legislative streamlining that the purpose of the law was perverted in many ways. Devised as an anti-chain measure, discriminatory chain taxes have had their most important effect on multiple retail units operated not by chains but by oil refinery companies. Existing taxes and the threat of future taxation caused oil companies to divest themselves of their holdings of filling stations. Another effect of chain taxes has been the formation of supermarkets in the grocery field. In fact, the transformation of many small chain-store units into large supermarkets is directly traceable to the desire of corporate chain stores to avoid the relatively small profits of a chain neighborhood store. Undoubtedly, the consolidation of small stores into large potent supermarkets has injured rather than helped the small independent grocer for whose benefit the tax protagonists had struggled. But here, as in the field of the Robinson-Patman price control attempts, it is diffcult to determine with mathematical exactitude the strength of legislative and marketing forces which join to make our distributive structure at once more competitive and more monopolistic.

\footnotetext{
${ }^{28}$ For an analysis of chain tax legislation see Wolff, supra note 5; cf. Feldman, Legislative Opposition to the Chain Store and Its Minimization, infra this issue.
} 